\title{
Smart edible films based on gelatin and curcumin
}

\author{
Yanina S. Musso a, b, Pablo R. Salgado a, b, Adriana N. Mauri a, b, * \\ a Centro de Investigación y Desarrollo en Criotecnología de Alimentos (CIDCA), CONICET CCT La Plata y Facultad de Ciencias Exactas, Universidad Nacional \\ de La Plata, 47 y $116 \mathrm{~S} / \mathrm{N}^{\circ}$, B1900JJ, La Plata, Argentina \\ ${ }^{\mathrm{b}}$ Consejo Nacional de Investigaciones Científicas y Técnicas (CONICET), Av. Rivadavia 1917, C1033AAJ, Ciudad de Buenos Aires, Argentina
}

\section{A R T I C L E I N F O}

\section{Article history:}

Received 10 August 2016

Received in revised form

4 November 2016

Accepted 7 November 2016

Available online 9 November 2016

\section{Keywords:}

Smart packaging

Curcumin

Protein film

$\mathrm{pH}$ indicators

Gelatin

Food spoilage sensor

\begin{abstract}
A B S T R A C T
This work studied the preparation of edible smart films based on gelatin and curcumin. Films were prepared by casting using water and an ethanol-water mixture as solvents. The addition of curcumin, besides affecting the physicochemical properties of gelatin films, colored them depending on the $\mathrm{pH}$ of the film-forming dispersion (yellow at $\mathrm{pH}=6$ and red at $\mathrm{pH}=11$ ). It also provided films with important antioxidant properties, but no antimicrobial activity. The response of these materials against $\mathrm{pH}$ changes was evaluated simulating their contact with liquid and semisolid foods, and with a container headspace at acid and alkaline $\mathrm{pH}$. In all tests, gelatin films with curcumin added could modify their color after being in contact with media of different $\mathrm{pH}$. The use of an ethanol-water mixture as solvent was a good alternative to intensify film color and the visualization of their response capacity against $\mathrm{pH}$ changes, as well as to increase the antioxidant properties and hydrophobicity of films. These edible films could be used as smart food packaging, since they could inform consumers if the product was suitable for consumption through their capacity to sense pH changes.
\end{abstract}

() 2016 Published by Elsevier Ltd.

\section{Introduction}

Changes in consumer preferences have led to innovations and developments in new packaging technologies. 'Smart packaging' is a broad term encompassing a range of relatively new packaging concepts, most of which can be placed in one of the two main categories: active packaging and intelligent packaging (Kerry, 2012). Active packaging has been defined as one that changes the condition of packed food to extend shelf-life or to improve safety or sensory properties maintaining its quality, whereas intelligent ones refer to those which monitor the condition of packaged foods to give information about their quality to manufacturers, retailers or consumers (Ahvenainen, 2003). These last materials often attempt to sense environmental changes or specific compounds generated during food packaging or storage, in order to inform the freshness or microbiological quality of food (Biji, Ravishankar, Mohan, \& Srinivasa Gopal, 2015). Media pH could be modified during food storage, through changes in the concentrations of organic acids

\footnotetext{
* Corresponding author. Centro de Investigación y Desarrollo en Criotecnología de Alimentos (CIDCA), CONICET CCT La Plata y Facultad de Ciencias Exactas, Universidad Nacional de La Plata, 47 y 116 S/N , B1900JJ, La Plata, Argentina.

E-mail address: anmauri@quimica.unlp.edu.ar (A.N. Mauri).
}

(such as $n$-butyrate, $L$-lactic acid, $D$-lactate and acetic acid), and volatile compounds development (such as trimethylamine, dimethylamine, histamine, hypoxanthine, putrescine, tyramine, cadaverine, and hydrogen sulphide, among others) as a result of microorganisms growth and metabolism (Al Bulushi, Poole, Deeth, \& Dykes, 2009; Ruiz-Capillas \& Jiménez-Colmenero, 2005). Thus, $\mathrm{pH}$ changes could be considered as potential indicators of food spoilage.

In previous work (Musso, Salgado, \& Mauri, 2016), gelatin-based films capable of sensing changes in the surrounding $\mathrm{pH}$ medium were developed by adding known acid-base indicators methyl orange, neutral red and bromocresol green to the formulation. These indicators were used as model systems to test if proteins that can act as buffer systems, due to their chain ionizable side groups, allowed films to change their color when in contact with gaseous, liquid and semisolid media with a different $\mathrm{pH}$. Evidence showing that the protein matrix did not interfere with the possible discoloration of the acid-base indicators and the fact that films could change their color according to media $\mathrm{pH}$, pushed to find food grade dyes that could replace these synthetic indicators in order to develop real food packaging materials capable of sensing $\mathrm{pH}$ changes.

Curcumin is the product obtained by solvent extraction from 
turmeric - the ground rhizomes of Curcuma longa L. - and later purification by crystallization. It is widely used as a spice and coloring agent in food by virtue of its yellowish-orange color and pleasant aroma (Martins, Roriz, Morales, Barros, \& Ferreira, 2016). It has also been used in a variety of pharmaceutical applications, because it exhibited many interesting biological activities such as antiviral, anti-inflammatory, antimicrobial, antioxidant, anti-HIV, anti-Parkinson, anti-Alzheimer's, anti-angiogenesis, free radical scavenging activity, and anticancer (Pulido-Moran, MorenoFernandez, Ramirez-Tortosa, \& Ramirez-Tortosa, 2016). The IUPAC name of curcumin is (1E,6E)-1,7-bis(4-hydroxy-3-methoxyphenyl)1,6hepadiene-3,5-dione. In solution, it exhibits a keto-enol tautomerism and, depending on the solvent, up to 95\% could be in the enol form. In the $\mathrm{pH}$ range $1-7$, the majority of diferuloyl methane species are in the neutral form, water solubility is very low and solutions are yellow. At $\mathrm{pH}>8.5$, solutions changed their color to red and their water solubility barely increased. However, due to its chemical structure, curcumin is highly soluble in ethanol, chloroform, dimethyl sulfoxide and oils (Mehanny, Hathout, Geneidi, \& Mansour, 2016; Priyadarsini, 2014).

Curcumin was added in natural and synthetic polymer films in order to provide them with antioxidant and antimicrobial properties (Bajpai, Chand, \& Ahuja, 2015; Govindaraj, Kandasubramanian, \& Kodam, 2014; Liu, Cai, Jiang, Wu, \& Le, 2016; Mayet et al., 2014). Maniglia, Domingos, de Paula, and Tapia-Blácido (2014) and Maniglia, de Paula, Domingos and Tapia-Blácido (2015) used turmeric dye extraction residue for the production of bioactive films. As far as we know, only Kuswandi, Jayus, Larasati, Abdullah, \& Heng (2012) used curcumin to develop a sensor for the detection of volatile amines. They did it by the absorption method of curcumin onto bacterial cellulose membrane (also called nata de coco), and used it as a sticker sensor for real-time monitoring of shrimp spoilage, as this membrane was highly sensitive toward acid-base reactions.

The aim of this work was to prepare active gelatin films capable of sensing $\mathrm{pH}$ changes by the addition of curcumin to films formulations. Taking into account the hydrophobicity of curcumin and the fact that films were obtained by a casting technique, water and an ethanol-water mixture were analyzed as solvents for filmforming dispersions.

\section{Material and methods}

\subsection{Materials}

Bovine gelatin with 240 Bloom (Kraft Foods, Argentina) was used as protein source. Its protein content, as measured by the Kjeldahl method (AOAC, 1995), was $87.8 \pm 0.6 \%$ (w/w, dry weight; $\mathrm{N} \times 5.5$ ). Glycerol (Anedra, Argentina) was used as film plasticizer. Curcumin (Chr Hansen, Argentina) was used as colorant. All the other reagents used in this study were of analytical grade.

Table 1

Film nomenclature and final formulation of film-forming dispersions.

\begin{tabular}{|c|c|c|c|c|c|}
\hline \multirow[t]{2}{*}{ Film nomenclature } & \multicolumn{5}{|c|}{ Final formulation of film-forming dispersions } \\
\hline & Gelatin (\% w/v) & Glycerol (\% w/v) & Curcumin $(\% \mathrm{w} / \mathrm{v})$ & $\mathrm{pH}$ & Solvent \\
\hline Gw6 & 5 & 1.25 & - & 6 & Water \\
\hline Gw11 & 5 & 1.25 & - & 11 & Water \\
\hline GCw6 & 5 & 1.25 & 0.02 & 6 & Water \\
\hline GCw11 & 5 & 1.25 & 0.02 & 11 & Water \\
\hline Gew6 & 5 & 1.25 & - & 6 & Ethanol-water mixture $^{a}$ \\
\hline Gew11 & 5 & 1.25 & - & 11 & Ethanol-water mixture \\
\hline GCew6 & 5 & 1.25 & 0.02 & 6 & Ethanol-water mixture ${ }^{a}$ \\
\hline GCew11 & 5 & 1.25 & 0.02 & 11 & Ethanol-water mixture $^{a}$ \\
\hline
\end{tabular}

\subsection{Films preparation}

Films were prepared by casting using water and an ethanolwater mixture $(1: 1 \mathrm{v} / \mathrm{v})$ as solvents. In each case, two dispersions were prepared separately: one containing $10 \% \mathrm{w} / \mathrm{v}$ of gelatin in water at $100{ }^{\circ} \mathrm{C}$ and another containing $0.04 \% \mathrm{w} / \mathrm{v}$ of curcumin in water or ethanol respectively, at ambient temperature. Equal volumes of protein and curcumin dispersions were mixed with magnetic stirring, adding glycerol $(1.25 \% \mathrm{w} / \mathrm{v})$ as plasticizer and the $\mathrm{pH}$ of each dispersion was adjusted to 6 and 11 with $2 \mathrm{~mol} / \mathrm{L} \mathrm{HCl}$ and $2 \mathrm{~mol} / \mathrm{L} \mathrm{NaOH}$ respectively. Finally, $10 \mathrm{~mL}$ of each film-forming dispersion were cast onto polystyrene Petri dishes $\left(64 \mathrm{~cm}^{2}\right)$ and dried in an oven with air flow circulation (Yamato, DKN600, USA) at $60{ }^{\circ} \mathrm{C}$ for $3 \mathrm{~h}$. The resulting films were preconditioned during $48 \mathrm{~h}$ at $20^{\circ} \mathrm{C}$ and $58 \%$ relative humidity (in desiccators with saturated solutions of $\mathrm{NaBr}$ ) just before being peeled from the casting surface and characterized. Furthermore, control gelatin films without the incorporation of curcumin in both solvents at $\mathrm{pH}=6$ and 11, were prepared as described previously. Table 1 summarizes film nomenclature and the final formulation of film-forming dispersions.

Three independent batches for each type of protein film were performed.

\subsection{Films characterization}

\subsubsection{Thickness}

Film thickness was measured by a digital coating thickness gauge (Check Line DCN-900, USA). Measurements were done at five positions along the rectangular strips for the tensile test, and at the center and at eight positions round the perimeter for the water vapor permeability (WVP) determinations. The mechanical properties and WVP were calculated using the average thickness for each film replicate.

\subsubsection{Color}

Film color was determined with a Konica Minolta Chroma Meter CR-400 (Konica Minolta Chroma Co., Osaka, Japan) set to C illuminant $/ 2^{\circ}$ observer. A CIE-Lab color scale was used to measure the degree of lightness $\left(L^{*}\right)$, redness $\left(+a^{*}\right)$ or greenness $\left(-a^{*}\right)$, and yellowness $\left(+b^{*}\right)$ or blueness $\left(-b^{*}\right)$ of the films. The instrument was calibrated using a white standard plate with color coordinates of $L_{\text {standard }}^{*}=97.55, a_{\text {standard }}^{*}=-0.03$ and $b_{\text {standard }}=1.73$ provided by Minolta. Films color was measured on the surface of this standard plate and total color difference $\left(\Delta E^{*}\right)$ was calculated as follow:

$$
\begin{aligned}
\Delta E^{*} & =\left[\left(L_{\text {film }}^{*}-L_{\text {standard }}^{*}\right)^{2}+\left(a_{\text {film }}^{*}-a_{\text {standard }}^{*}\right)^{2}\right. \\
& \left.+\left(b_{\text {film }}^{*}-b_{\text {standard }}^{*}\right)^{2}\right]^{0.5}
\end{aligned}
$$

\footnotetext{
${ }^{\mathrm{a}}$ Ethanol-water mixture $(1: 1 \mathrm{v} / \mathrm{v})$.
} 
Values were expressed as the means of nine measurements on different areas of each film.

\subsubsection{UV-visible absorption spectra}

Each film specimen was cut into a rectangular piece and placed directly in a spectrophotometer test cell. A spectrum (from 200 to $800 \mathrm{~nm}$ ) of each film was obtained in an UV-Vis spectrophotometer (Biotek, synergy HT, USA). Measurements were performed using air as reference. All determinations were performed in triplicate.

\subsubsection{Moisture content (MC)}

Small specimens of films were collected after conditioning, cut and weighed before and after oven drying at $105^{\circ} \mathrm{C}$ for $24 \mathrm{~h}$, ASTM D644-99, (ASTM, 2004). MC values were determined in triplicate for each film, and calculated as the percentage of weight loss relative to the original weight.

\subsubsection{Water solubility (WS)}

WS was determined as was described by Gontard, Duchez, Cuq, and Guilbert (1994) with slight modifications. Three pieces of films were weighed (diameter $=2 \mathrm{~cm} ; \sim 0.03-0.05 \mathrm{~g}$ ) and immersed in $50 \mathrm{~mL}$ of distilled water. The system was sealed, shaken at $100 \mathrm{rpm}$ for $24 \mathrm{~h}$ at $20^{\circ} \mathrm{C}$ (Ferca, TT400 model, Argentina), and then filtered through Whatman $n^{\circ} 1$ filter paper (previously dried and weighed) to recover the remaining undissolved film, which was desiccated at $105{ }^{\circ} \mathrm{C}$ for $24 \mathrm{~h}$. WS was calculated as follows:

$\mathrm{WS}=\left[\left(\mathrm{P}_{0} \cdot(100-\mathrm{MC})\right)-\mathrm{P}_{\mathrm{f}}\right] \cdot 100 /\left[\mathrm{P}_{0} \cdot(100-\mathrm{MC})\right]$

Where $\mathrm{P}_{0}=$ initial film weight $(\mathrm{g}), \mathrm{P}_{\mathrm{f}}=$ final dry film weight $(\mathrm{g})$, $\mathrm{MC}=$ moisture content (\%). All tests were carried out in triplicate.

\subsubsection{Water vapor permeability (WVP)}

Water vapor permeability tests were conducted according to ASTM method E96-00 (ASTM, 2004) with some modifications. Each film sample was sealed over a circular opening of $0.00185 \mathrm{~m}^{2}$ in a permeation cell that was stored at $20^{\circ} \mathrm{C}$ in desiccators. To maintain a $75 \%$ relative humidity $(\mathrm{RH})$ gradient across the film, anhydrous silica $\left(0 \% \mathrm{RH}_{\mathrm{c}}\right)$ was placed inside the cell and a saturated $\mathrm{NaCl}$ solution $\left(75 \% \mathrm{RH}_{\mathrm{d}}\right)$ was used in the desiccators. The $\mathrm{RH}$ inside the cell was always lower than outside, and water vapor transport was determined from the weight gain of the permeation cell. When steady-state conditions were reached (about $1 \mathrm{~h}$ ), eight weight measurements were made over $5 \mathrm{~h}$. Changes in the weight of the cell were recorded and plotted as a function of time. The slope of each curve $\left(\Delta m / \Delta t, \mathrm{~g} \mathrm{H}_{2} \mathrm{O} \mathrm{s}^{-1}\right)$ was obtained by linear regression and the water vapor transmission rate (WVTR) was calculated from the slope divided by the permeation cell area $\left(\mathrm{A}\right.$, in $\left.\mathrm{m}^{2}\right)$. WVP $(\mathrm{g}$ $\mathrm{H}_{2} \mathrm{O} \mathrm{Pa} \mathrm{Pa}^{-1} \mathrm{~s}^{-1} \mathrm{~m}^{-1}$ ) was calculated as:

$\mathrm{WVP}=\left[\mathrm{WVTR} /\left(\mathrm{P}_{\mathrm{V}}^{\mathrm{H} 2 \mathrm{O}} \cdot\left(\mathrm{RH}_{\mathrm{d}}-\mathrm{RH}_{\mathrm{c}}\right)\right)\right] \cdot \mathrm{d}$

where: WVTR = water vapor transmission rate $\left(\mathrm{g} \mathrm{H}_{2} \mathrm{O} \mathrm{s}^{-1} \mathrm{~m}^{-2}\right)$, $\mathrm{PV}^{\mathrm{H} 2 \mathrm{O}}=$ saturation water vapor pressure at test temperature (2339.27 $\mathrm{Pa}$ at $\left.20^{\circ} \mathrm{C}\right), \mathrm{RH}_{\mathrm{d}}-\mathrm{RH}_{\mathrm{C}}=$ relative humidity gradient across the film -expressed as a fraction- $(0.75), \mathrm{A}=$ permeation area $\left(\mathrm{m}^{2}\right)$, and $d=$ film thickness $(\mathrm{m})$. Each WVP value represents the mean value of three samples taken from different films.

\subsubsection{Mechanical properties}

Tensile strength (TS), Young's modulus (YM) and elongation at break (EAB) of films were determined following the procedures outlined in the ASTM method D882-02 (ASTM, 2004), using a texture analyzer TA.XT2i (Stable Micro Systems, Surrey, England) equipped with a tension grip system A/TG. Films probes of $90 \mathrm{~mm}$ length and $6 \mathrm{~mm}$ width were used. The initial grip separation was set at $50 \mathrm{~mm}$ and the crosshead speed at $0.4 \mathrm{~mm} \mathrm{~s}^{-1}$. Measurements were made at $20{ }^{\circ} \mathrm{C}$ in a temperature-controlled room. The curves of force $(\mathrm{N})$ as a function of distance $(\mathrm{mm})$ were recorded by the Texture Expert V.1.15 software (Stable Micro Systems, Surrey, England). Tensile properties were calculated from the plot of stress (tensile force/initial cross-sectional area) versus strain (extension as a percentile of the original length). TS and EAB were determined directly from the stresses-train curves, and YM was determined as the slope of the initial linear portion of this curve. Reported values are the average of at least twelve replications taken from different films for each formulation.

\subsection{Antioxidant and antimicrobial properties of films}

\subsubsection{Antioxidant capacity of films}

The supernatants obtained in the WS test were used for testing the film antioxidant capacity based on two different antioxidant mechanisms: the radical scavenging capacity and the reducing capacity.

The radical scavenging capacity was measured using ABTS •+ (2,2'-azino-bis-(3-ethylbenzothiazoline-6-sulfonic acid)) radical cation decoloration assay according to Salgado, López-Caballero, Gómez-Guillén, Mauri, and Montero (2012). Samples were mixed with ABTS reagent. The mixture was then left to stand at $30^{\circ} \mathrm{C}$ for $10 \mathrm{~min}$ and absorbance values were read at $734 \mathrm{~nm}$ (Biotek, synergy HT, USA). Results were expressed as concentration of ascorbic acid equivalent per $g$ of protein film based on a standard curve of ascorbic acid, which relates the concentration to the absorbance at $734 \mathrm{~nm}$. Determinations were carried out in triplicate.

The reducing capacity was measured following the ferric ion reducing capacity (FRAP) assay, according to Salgado et al. (2012). Samples were incubated (at $37{ }^{\circ} \mathrm{C}$ ) with distilled water and FRAP reagent (containing 2,4,6-tripyridyl-s-triazine and $\mathrm{FeCl}_{3} \cdot 7 \mathrm{H}_{2} \mathrm{O}$ ) in sodium acetate buffer $\mathrm{pH}$ 3.6. Absorbance values were read at $595 \mathrm{~nm}$ after $30 \mathrm{~min}$ (Biotek, synergy HT, USA). Results were expressed as $\mathrm{mmol} \mathrm{FeSO}_{4} \cdot 7 \mathrm{H}_{2} \mathrm{O}$ equivalents per $\mathrm{g}$ of protein film based on a standard curve of $\mathrm{FeSO}_{4} \cdot 7 \mathrm{H}_{2} \mathrm{O}$, which relates the concentration to the absorbance at $595 \mathrm{~nm}$. All determinations were carried out in triplicate.

\subsubsection{Antimicrobial properties of films}

The "zone of inhibition" assay on solid media was used for determination of the antimicrobial effects of gelatin films against Salmonella enteritidis, Escherichia coli, Bacillus cereus, and Staphylococcus aureus (Salgado, López-Caballero, Gómez-Guillén, Mauri, \& Montero, 2013). Gelatin films were aseptically cut into $10 \mathrm{~mm}$ diameter discs and then placed on solid nutrient agar (Biokar diagnostics) plates, which had been previously spread with $10 \mu \mathrm{L}$ of inoculum containing $10^{8} \mathrm{CFU} / \mathrm{mL}$ of tested bacterium. Plates were incubated at $37^{\circ} \mathrm{C}$ for $48 \mathrm{~h}$. The plates were examined visually for "zone of inhibition" of the film discs, and the diameter of the zone was measured with a gauge. Tests were done in duplicate.

\subsection{Films response to $\mathrm{pH}$ changes}

Each film was faced with liquid, semisolid and gaseous media of different $\mathrm{pH}$ : i) adding a drop of $2 \mathrm{~mol} / \mathrm{L} \mathrm{HCl}$ or $2 \mathrm{~mol} / \mathrm{L} \mathrm{NaOH}$ directly on films; ii) placing the films in contact with gels prepared from gelatin solutions at $7.5 \% \mathrm{w} / \mathrm{v}$ at $\mathrm{pH}=2.5$, and 11 ; and iii) exposing the films to gaseous atmospheres generated by acetic acid glacial $\left(\mathrm{C}_{2} \mathrm{H}_{4} \mathrm{O}_{2}, \mathrm{pK}_{\mathrm{a}} \sim 4.8\right.$, Anedra, Argentina) and ammonia $\left(\mathrm{NH}_{3}\right.$, $\mathrm{pK}_{\mathrm{a}} \sim 9.3$, Anedra, Argentina) (Musso et al., 2016). Photographs of films before and after 30 min contacting it with those media of 
different pH were taken with a digital camera (Kodak M853, USA) and color variations were measured using a colorimeter (Konica Minolta Chroma Meter CR-400), as described above.

\subsection{Statistical analysis}

Results were expressed as mean \pm standard deviation and were analyzed by analysis of variance (ANOVA). Means were tested with the Tukey's HSD (Honestly Significant Difference) test for paired comparison, with a significance level $\alpha=0.05$, using the Statgraphics Plus version 5.1 software (Statgraphics, USA).

\section{Results and discussion}

\subsection{Appearance and optical properties of films}

Gelatin films prepared with or without curcumin from aqueous or hydroalcoholic dispersions at $\mathrm{pH} 6$ or 11 were homogeneous, thin and flexible. Fig. 1 shows their visual appearance. Gelatin films were colorless regardless of $\mathrm{pH}$ and the solvent used, while those with curcumin added became yellow and orange-red, depending on whether the dispersion $\mathrm{pH}$ was 6 or 11. These colorations were more intense for films prepared using the ethanol-water mixture as a solvent.

Color parameters $\mathrm{L}^{*}, a^{*}, b^{*}$ and $\Delta E^{*}$ of the studied films are shown in Table 2. Gelatin films of different $\mathrm{pH}$ did not show significant differences in color parameters -with the exception of those prepared with the ethanol-water mixture at $\mathrm{pH} 6$ which present a higher $b^{*}$ value-, being those obtained with ethanolwater mixtures rather clearer (higher $L^{*}$ ) than those obtained with only water as a solvent $(\mathrm{p}<0.05)$. Gelatin films prepared with curcumin showed a significant increase $(\mathrm{p}<0.05)$ in $a^{*}, b^{*}$ and $\Delta E^{*}$ values and a significant decrease $(\mathrm{p}<0.05)$ in $L^{*}$. This tendency was more marked for the films prepared using the ethanol-water mixture as solvent.
Table 2

CIE-Lab color parameters $\left(L^{*}, a^{*}\right.$ and $\left.b^{*}\right)$ and total color difference $\left(\Delta E^{*}\right)$ of gelatinbased films $(G)$ and those with curcumin added (GC) obtained with different solvents - water (w) and an ethanol-water mixture (ew)- at different $\mathrm{pH}$ (6 and 11).

\begin{tabular}{lllll}
\hline Film & $L^{*}$ & $a^{*}$ & $b^{*}$ & $\Delta E^{*}$ \\
\hline Gw6 & $93.3 \pm 0.5^{\mathrm{e}}$ & $-0.94 \pm 0.07^{\mathrm{a}}$ & $2.7 \pm 0.6^{\mathrm{a}}$ & $1.8 \pm 0.5^{\mathrm{a}}$ \\
Gw11 & $93.9 \pm 0.6^{\text {ef }}$ & $-1.07 \pm 0.07^{\mathrm{a}}$ & $2.0 \pm 0.1^{\mathrm{a}}$ & $2.6 \pm 0.2^{\mathrm{a}}$ \\
GCw6 & $89.1 \pm 0.4^{\mathrm{d}}$ & $-2.40 \pm 0.20^{\mathrm{a}}$ & $39.3 \pm 1.7^{\mathrm{d}}$ & $38.3 \pm 1.7^{\mathrm{c}}$ \\
GCw11 & $83.1 \pm 3.3^{\mathrm{c}}$ & $7.70 \pm 0.20^{\mathrm{b}}$ & $25.1 \pm 0.9^{\mathrm{c}}$ & $27.9 \pm 0.8^{\mathrm{b}}$ \\
Gew6 & $96.2 \pm 0.7^{\mathrm{ef}}$ & $-0.70 \pm 0.10^{\mathrm{a}}$ & $5.4 \pm 0.3^{\mathrm{a}}$ & $3.5 \pm 0.7^{\mathrm{a}}$ \\
Gew11 & $97.3 \pm 0.3^{\mathrm{f}}$ & $-0.40 \pm 0.01^{\mathrm{a}}$ & $2.4 \pm 0.5^{\mathrm{a}}$ & $3.4 \pm 0.3^{\mathrm{a}}$ \\
GCew6 & $72.6 \pm 3.4^{\mathrm{b}}$ & $21.3 \pm 3.00^{\mathrm{c}}$ & $86.4 \pm 6.0^{\mathrm{e}}$ & $90.5 \pm 4.3^{\mathrm{e}}$ \\
GCew11 & $28.0 \pm 2.2^{\mathrm{a}}$ & $35.8 \pm 3.70^{\mathrm{d}}$ & $19.1 \pm 1.9^{\mathrm{b}}$ & $80.3 \pm 6.1^{\mathrm{d}}$ \\
\hline
\end{tabular}

Reported values for each gelatin film are means \pm standard deviation $(n=9)$. Different letters in the same column indicate significant differences between samples ( $\mathrm{p}<0.05$ ), according to Tukey's test.

A more intense coloration in hydroalcoholic films can be due to curcumin's higher solubility in this medium than in water because of its hydrophobic nature (Priyadarsini, 2014). Supplementary Fig. 1 shows the appearance of curcumin dispersions in both solvents. The development of color in these systems might imply that water can disperse it (panel A), whereas the hydroalcoholic mixture seems to dissolve it completely (panel B). The addition of gelatin and glycerol to the system (Supplementary Fig. 1, panels C and D) apparently improves colorant dispersion and even modify its tonality, especially in aqueous dispersions.

Fig. 2 shows the UV-visible absorption spectra of studied films. Those prepared only with gelatin (Gw6, Gw11, Gew6, and Gew11) showed the same spectra regardless of the $\mathrm{pH}$ and solvent used in film-forming solutions. They showed two absorption peaks at $205 \mathrm{~nm}$ and $230 \mathrm{~nm}$ attributed to peptide bonds, another at 260-280 nm corresponding to the aromatic amino acids absorption, and a minimum absorbance in the complete visible spectra range. Priyadarsini (2014) reported that the absorption spectrum of curcumin has two strong absorption bands, one in the UV region

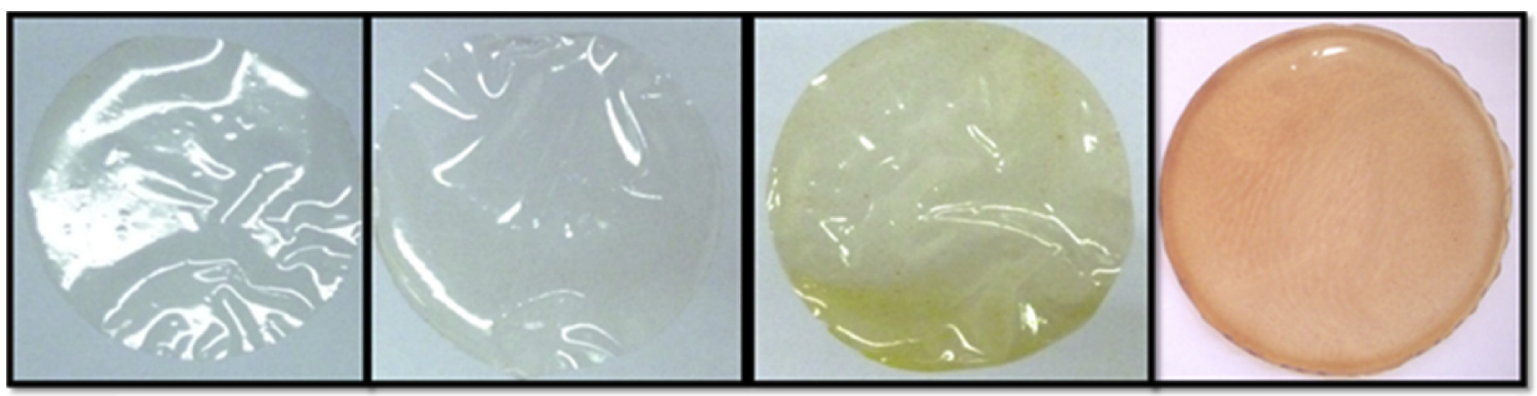

\section{Gw6 \\ Gw11 \\ GCw6 \\ GCw11}

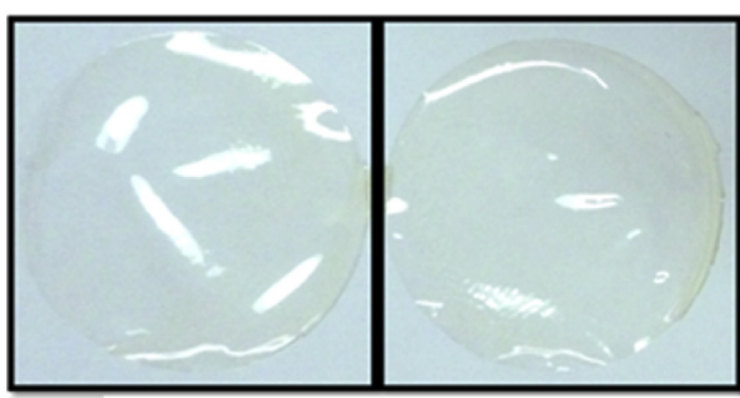

Gew6
Gew11

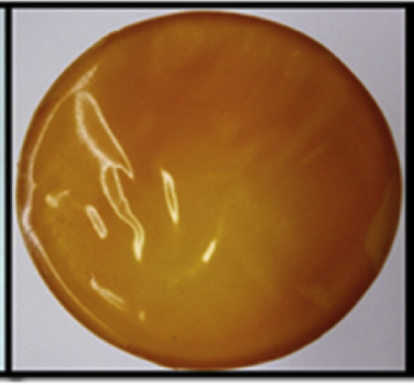

GCew6

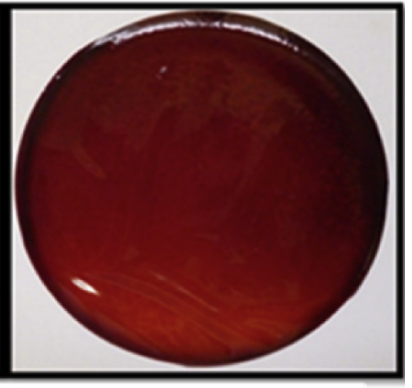

GCew11

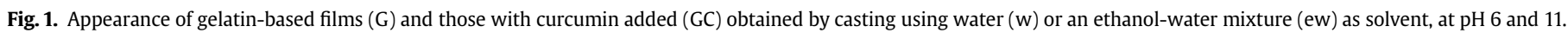




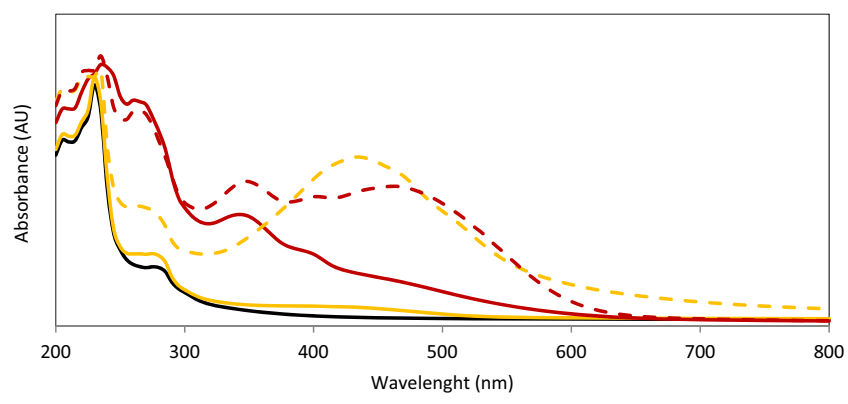

Fig. 2. UV-Visible absorption spectra $(200-800 \mathrm{~nm})$ of gelatin-based films (G) and those with curcumin added (GC) obtained using water (w) or an ethanol-water mixture (ew) as solvent, at different $\mathrm{pH}$ (6 and 11). Spectra of gelatin-based films without curcumin are superimposed: (-) Gw6, Gw11, Gew6 and Gew11. Spectra of gelatin films with curcumin added: $(-)$ GCw6; $(-)$ GCw11; (---) GCew6 and (---) GCew11.

with maximum at $265 \mathrm{~nm}$ and another one in the visible region with a maximum ranging from 410 to $430 \mathrm{~nm}$. The addition of curcumin into gelatin films increased the absorption peaks in the UV region, especially the one at 260-265 nm. Films at pH 11 (GCw11 and GCew11) showed two new absorption peaks in the UV region with maximums at $345 \mathrm{~nm}$ and $395 \mathrm{~nm}$, which could be attributed to curcumin degradation products under alkaline conditions, like trans-6(4'-hydroxy-3'-methoxyphenyl)-2,4-dioxo-5hexanal, ferulic aldehyde, ferulic acid, feruloylmethane and vanillin (Wang et al., 1997). Moreover, in the visible range of the spectra, yellow gelatin-curcumin films at pH 6 (GCw6 and GCew6) had an absorption peak at $420 \mathrm{~nm}$, while those at pH 11 (GCw11 and
GCew11) showed it at $460 \mathrm{~nm}$ according to their red coloring. These results also agree with those of Priyadarsini (2014), who reported that the absorption peak of curcumin was at $420 \mathrm{~nm}$ at $\mathrm{pH}<7.5$ and at $467 \mathrm{~nm}$ at $\mathrm{pH}>10$. It is worth noting that the gelatin-curcumin films prepared from hydroalcoholic dispersions (GCew6 and GCew11) presented higher absorbance in the entire UV-visible range than those prepared from aqueous dispersions at the same pH (GCw6 and GCw11) due to the better solubilization of curcumin.

\subsection{Film response to $\mathrm{pH}$ changes}

Fig. 3 shows the response of all gelatin-curcumin films (GCw6, GCw11, GCew6, and GCew11) when in contact with acid and alkali liquids, semisolids and gases. All films showed the ability to sense $\mathrm{pH}$ changes, simulating that these changes could occur in a liquid or semisolid food, or in the headspace of a food container as the result of the reaction products of food spoilage. Yellow films at $\mathrm{pH} 6$ (GCw6 and GCew6) turned to orange-red when in contact with alkaline gases, liquids and semisolids while orange-red films (GCw11 and GCew11) at pH 11 turned yellow in contact with acid media. And as expected, those films whose $\mathrm{pH}$ was near the one of the media did not change their color. Changes were more noticeable in those films obtained from hydroalcoholic dispersions due to their more intense coloration. Film responses were immediate and marked with liquid and gases of different $\mathrm{pH}$, but less evident and slower with a semisolid medium, especially with films prepared from aqueous dispersions. Slower turning kinetics against semisolid media could probably be attributed to limited diffusive processes (Musso et al., 2016). Kuswandi, Jayus, Abdullah, Heng, and
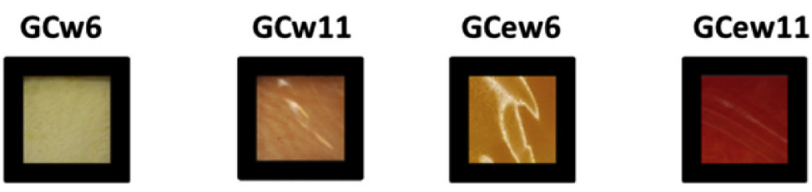

Response to:

Acid liquid medium $(\mathrm{HCl})$
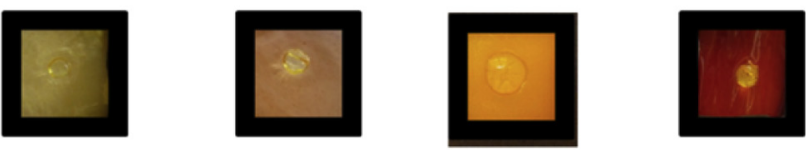

Basic liquid medium ( $\mathrm{NaOH})$
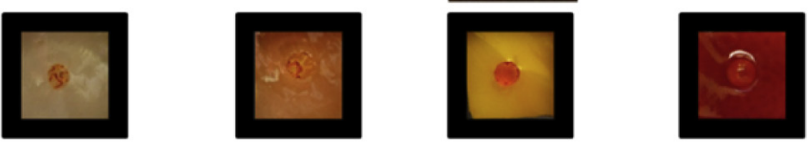
Acid gaseous medium $\left(\mathrm{C}_{2} \mathrm{H}_{4} \mathrm{O}_{2}\right)$
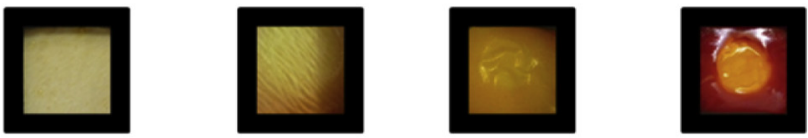

Basic gaseous medium $\left(\mathrm{NH}_{3}\right)$
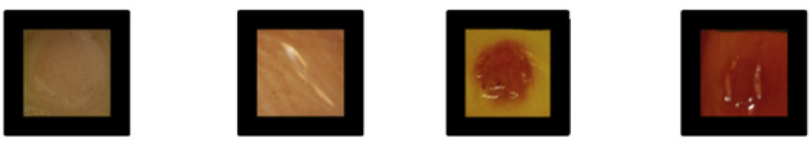

Gelatin gel at $\mathrm{pH}: 6$
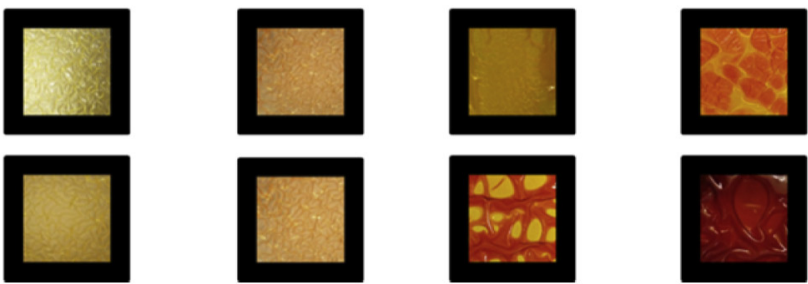

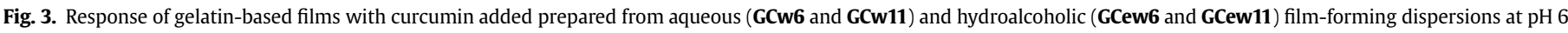
and 11 after being in contact with liquid, gaseous and semisolid media of different $\mathrm{pH}$. 
Table 3

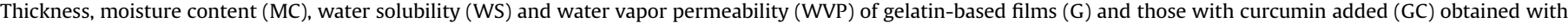
different solvents - water (w) and an ethanol-water mixture (ew)- at different $\mathrm{pH}(6$ and 11$)$.

\begin{tabular}{|c|c|c|c|c|}
\hline Film & Thickness ( $\mu \mathrm{m})$ & MC (\%) & WS (\%) & WVP $\times 1010\left(\mathrm{~g} \mathrm{H}_{2} \mathrm{O} /\right.$ Pa.s.m $)$ \\
\hline Gw6 & $51.0 \pm 2.3^{\mathrm{abc}}$ & $22.1 \pm 0.6^{\mathrm{e}}$ & $37.6 \pm 2.7^{\mathrm{ab}}$ & $6.5 \pm 0.3^{b}$ \\
\hline Gw11 & $47.8 \pm 3.4^{\mathrm{a}}$ & $21.4 \pm 0.2^{\mathrm{de}}$ & $34.6 \pm 1.8^{\mathrm{ab}}$ & $7.9 \pm 0.4^{c}$ \\
\hline GCw6 & $49.6 \pm 5.2^{\mathrm{ab}}$ & $18.9 \pm 0.5^{b c}$ & $30.3 \pm 4.7^{\mathrm{a}}$ & $1.0 \pm 0.01^{\mathrm{a}}$ \\
\hline GCw11 & $55.8 \pm 3.5^{\text {cde }}$ & $20.2 \pm 0.3^{\text {cde }}$ & $33.8 \pm 4.3^{\mathrm{ab}}$ & $0.9 \pm 0.03^{a}$ \\
\hline Gew6 & $62.4 \pm 3.5^{\mathrm{f}}$ & $16.9 \pm 0.7^{\mathrm{ab}}$ & $36.8 \pm 0.6^{\mathrm{ab}}$ & $1.1 \pm 0.3^{\mathrm{a}}$ \\
\hline Gew11 & $61.4 \pm 1.9^{\mathrm{ef}}$ & $16.6 \pm 0.3^{a}$ & $35.7 \pm 3.4^{\mathrm{ab}}$ & $1.2 \pm 0.3^{\mathrm{a}}$ \\
\hline GCew6 & $54.9 \pm 5.8^{\mathrm{bcd}}$ & $19.4 \pm 1.8^{\mathrm{cd}}$ & $41.2 \pm 3.2^{\mathrm{b}}$ & $1.2 \pm 0.08^{a}$ \\
\hline GCew11 & $58.2 \pm 5.9^{\mathrm{def}}$ & $21.3 \pm 0.6^{\mathrm{de}}$ & $39.3 \pm 2.2^{\mathrm{b}}$ & $1.2 \pm 0.4^{\mathrm{a}}$ \\
\hline
\end{tabular}

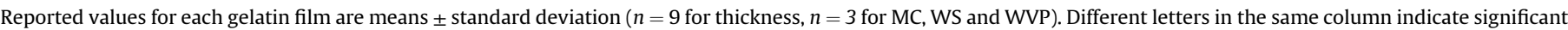
differences between samples ( $p<0.05$ ), according to Tukey's test.

Ahmad (2012) used a curcumin/bacterial cellulose sensor to measure the $\mathrm{pH}$ increase produced by the basic spoilage volatile amines gradually released in the shrimp package headspace, which subsequently changed its color from yellow to orange, and then to reddish orange as spoilage indication.

\subsection{Effects of $\mathrm{pH}$, solvent and curcumin addition on the physicochemical properties of films}

Table 3 shows the thickness, moisture content, water solubility and water vapor permeability of the studied films. Gelatin films prepared from aqueous dispersions were thinner than those prepared using the ethanol-water mixture as a solvent $(p<0.05)$. Ethanol can denature proteins by disrupting the side-chain intramolecular hydrogen bonding, and allowing the formation of new hydrogen bonds between alcohol molecules and protein sidechains. Salgado et al. (in press) showed how the conformation of proteins in the film-forming dispersions affects the physicochemical properties of films. It is evident that gelatin dissolved in ethanol-water mixtures produced films with a lower degree of compaction, suggesting different chain molecular unfolding or cross-linking within the protein network of the film (Denavi et al., 2009). These films showed lower moisture content and WVP $(p<0.05)$ and similar water solubility $(p>0.05)$ than those prepared from aqueous dispersions, regardless of the film-forming dispersion $\mathrm{pH}$. The addition of curcumin significantly increased $(\mathrm{p}<0.05)$ the thickness values of films prepared at $\mathrm{pH} 11$ in water and decreased $(\mathrm{p}<0.05)$ those of the films prepared at $\mathrm{pH} 6$ in ethanol-water. Curcumin also caused a decrease in the MC and WVP of films prepared from aqueous dispersions $(p<0.05)$ and only an increase in the MC of those prepared from hydroalcoholic dispersions $(p<0.05)$. It seems that both ethanol and curcumin increased the hydrophobic character of gelatin films, without affecting WS $(\mathrm{p}>0.05)$. In all cases, the $\mathrm{pH}$ of film-forming dispersions (both aqueous and hydroalcoholic) did not modify $(p>0.05)$ moisture content and water solubility of studied gelatin films with added curcumin or not. Only thickness and WVP were modified by changes in $\mathrm{pH}$ of aqueous film-forming dispersions: GCw11 was thicker than GCw6 ( $\mathrm{p}<0.05$ ), and Gw11 had higher WVP than Gw6 ( $\mathrm{p}<0.05$ ).

Table 4 shows the mechanical properties of films measured by tensile tests. Gelatin films obtained from aqueous dispersions showed mechanical properties similar to those published by other authors (Carvalho et al., 2008; Nur Hanani, Roos, \& Kerry, 2012). Particularly those at $\mathrm{pH} 11$ presented higher tensile strength and elongation at break but similar Young's modulus $(\mathrm{p}<0.05)$ than those at $\mathrm{pH} 6$, in concordance with previous results (Musso et al., 2016). With the addition of curcumin, as well as replacing the aqueous solvent by a hydroalcoholic mixture, films presented a significant decrease in Young's modulus (at least 50\%) $(\mathrm{p}<0.05)$.
Table 4

Tensile strength (TS), elongation at break (EAB), and Young's modulus (YM), of gelatin-based films $(\mathrm{G})$ and those with curcumin added (GC) obtained with different solvents - water (w) and an ethanol-water mixture (ew)- at different pH (6 and 11).

\begin{tabular}{llll}
\hline Film & TS $(\mathrm{MPa})$ & EAB $(\%)$ & YM $(\mathrm{MPa})$ \\
\hline Gw6 & $3.4 \pm 0.3^{\mathrm{c}}$ & $159.2 \pm 5.5^{\mathrm{ab}}$ & $0.15 \pm 0.07^{\mathrm{c}}$ \\
Gw11 & $4.6 \pm 0.1^{\mathrm{d}}$ & $206.9 \pm 6.0^{\mathrm{d}}$ & $0.13 \pm 0.09^{\mathrm{bc}}$ \\
GCw6 & $3.4 \pm 0.6^{\mathrm{c}}$ & $157.4 \pm 11.4^{\mathrm{ab}}$ & $0.06 \pm 0.005^{\mathrm{ab}}$ \\
GCw11 & $1.9 \pm 0.5^{\mathrm{ab}}$ & $176.5 \pm 20.0^{\mathrm{bc}}$ & $0.008 \pm 0.001^{\mathrm{a}}$ \\
Gew6 & $2.6 \pm 0.2^{\mathrm{b}}$ & $163.3 \pm 13.1^{\mathrm{ab}}$ & $0.06 \pm 0.01^{\mathrm{ab}}$ \\
Gew11 & $1.7 \pm 0.3^{\mathrm{a}}$ & $175.5 \pm 17.9^{\mathrm{bc}}$ & $0.01 \pm 0.001^{\mathrm{a}}$ \\
GCew6 & $1.9 \pm 0.1^{\mathrm{ab}}$ & $144.3 \pm 7.9^{\mathrm{a}}$ & $0.02 \pm 0.001^{\mathrm{a}}$ \\
GCew11 & $3.4 \pm 0.6^{\mathrm{c}}$ & $198.6 \pm 14.9^{\mathrm{cd}}$ & $0.007 \pm 0.001^{\mathrm{a}}$ \\
\hline
\end{tabular}

Reported values for each gelatin film are means \pm standard deviation $(n=12)$. Different letters in the same column indicate significant differences between samples ( $\mathrm{p}<0.05$ ), according to Tukey's test.

Curcumin also diminished the TS of alkaline films in both studied solvents but only the EAB of aqueous ones at $\mathrm{pH} 11(\mathrm{p}<0.05)$. Moreover, ethanol addition as solvent decreased TS of all films -except those with curcumin at $\mathrm{pH} 11-$, but only the EAB of films without curcumin at $\mathrm{pH} 11(\mathrm{p}<0.05)$.

However, it seems that both main effects, the presence of curcumin and the use of an ethanol-water mixture as a solvent, affect the cross-linking of gelatin films although no difference was observed in their water solubility. It is evident that when protein matrix hydrophobicity increases, due to modifications in its structure caused by changes in solvents, or by the addition of a more hydrophobic component such as curcumin, protein cross-linking changes, resulting in a decrease in the Young's modulus. But this change would not affect matrix stretching neither its water solubility significantly. The amino-acid composition of gelatin -low in sulfur-containing amino acids- explains this behavior. In other protein matrixes, such as soybean, sunflower, amaranth and gluten (among others), solubility and mechanical properties are determined by the possibility of cross-linking through disulfide bonds (Condés, Añón, \& Mauri, 2015; Mauri \& Añón, 2006; Salgado, Fernández, Drago, \& Mauri, 2011).

\subsection{Antioxidant and antimicrobial properties of films}

Fig. 4 shows the antioxidant properties of studied gelatin films as assessed by different methods: ABTS (A and $\mathbf{C}$ panels) and FRAP (B and D panels). Gelatin films without curcumin addition exhibited a low antioxidant capacity in both methods tested, especially at $\mathrm{pH} 6$. These results could be attributed in part to some gelatin amino acids that can act as electron donors, reacting with free radicals to give rise to more stable products in ABTS assay or reducing ferric ion in FRAP assay (Salgado et al., 2012). The addition of curcumin to formulations increased the antioxidant properties of resulting films significantly $(\mathrm{p}<0.05)$, being these increments 

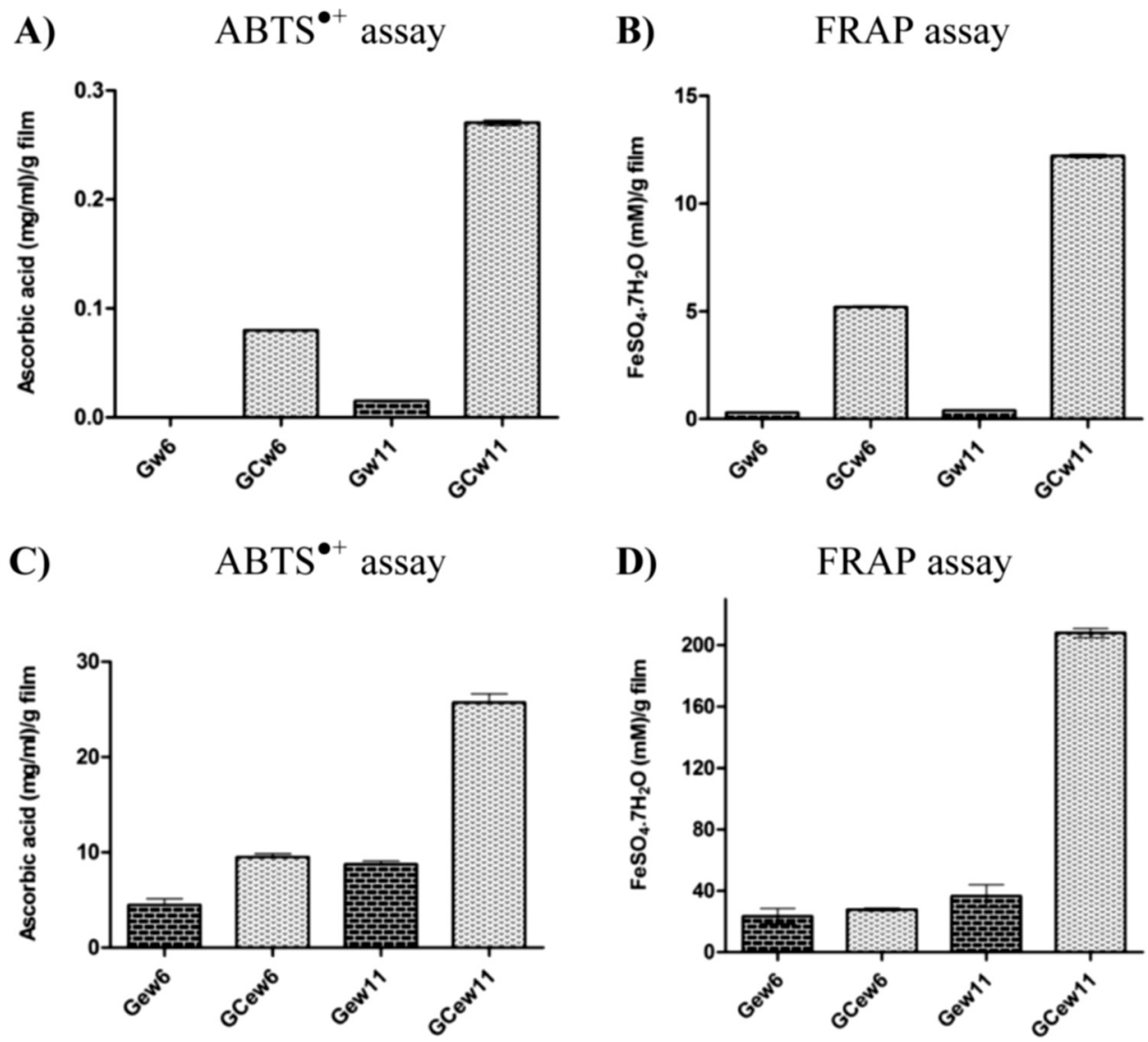

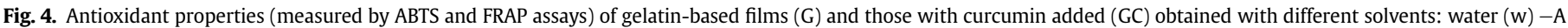
and B panels- and an ethanol-water mixture (ew) - B and D panels-, at different pH (6 and 11).

more noticeable at alkaline $\mathrm{pH}$ than at $\mathrm{pH} 6(\mathrm{p}<0.05)$. On the other hand, gelatin films with curcumin added or not, prepared from hydroalcoholic dispersions, showed higher antioxidant properties than those prepared using water as a solvent $(\mathrm{p}<0.05)$. Differences in protein cross-linking, as well as changes in the hydrophilichydrophobic nature of the protein matrix, should modify the retention or release of active principles in both gelatin and curcumin, affecting the antioxidant properties of the resulting films. As the chemical structure of curcumin changes with the $\mathrm{pH}$ of filmforming dispersions, it could differentially interact with gelatin, inducing films with different antioxidant properties. These results suggest that developed gelatin films with curcumin incorporated, especially those obtained using ethanol-water mixtures as a solvent at alkaline $\mathrm{pH}$, could be used as active films with an important antioxidant activity.

Despite the antimicrobial activity of curcumin against different fungal and bacterial strains and viruses reported in literature (Moghadamtousi et al., 2014), the gelatin-curcumin films showed no antimicrobial activity against $S$. enteritidis, E. coli, B. cereus, and $S$. aureus (data not shown). This result could be attributed, at least partly, to the low curcumin concentration employed in the studied films $(0.02 \% \mathrm{w} / \mathrm{v}$ in film-forming dispersions). Niamsa \& Sittiwet (2009) reported that an aqueous extract of C. longa had a minimum inhibitory concentration value of $4-32 \mathrm{~g} / \mathrm{L}$ against $S$. aureus and E. coli. On the other hand, Lawhavinit, Kongkathip, and Kongkathip (2010) reported that an alcoholic extract of turmeric had a minimum inhibitory concentration of $30 \mathrm{ppm}$ against S. aureus. The lack of antimicrobial activity in this work may also be attributed to interactions between curcumin and gelatin. Salgado et al. (2012) reported that sunflower protein films containing phenolic compounds did not show antimicrobial properties due to the important interactions between phenolic compounds and proteins in films at alkaline $\mathrm{pH}$.

\section{Conclusions}

It was possible to prepare smart gelatin films by adding curcumin to formulations. The resulting films showed antioxidant properties and were able to sense media $\mathrm{pH}$ by changing film color. Improvements in both behaviors were observed using ethanolwater mixtures instead of water as a solvent in film-forming dispersions. These films showed higher antioxidant activity and susceptibility to media $\mathrm{pH}$. These edible materials could be used as smart food packaging as they could provide information about food spoilage indirectly through media $\mathrm{pH}$ measurement and extend the shelf-life of food through the material's antioxidant properties.

\section{Acknowledgements}

The authors are thankful to the National Agency of Scientific and Technological Support (PICT-2010-1837, PICT-2013-2124) and the Universidad Nacional de La Plata (11/X618 and 11/X750) for their financial support.

\section{Appendix A. Supplementary data}

Supplementary data related to this article can be found at http:// dx.doi.org/10.1016/j.foodhyd.2016.11.007. 


\section{References}

Ahvenainen, R. (2003). Active and intelligent packaging: An introduction. In R. Ahvenainen (Ed.), Novel food packaging techniques (pp. 5-21). Cambridge: Woodhead.

Al Bulushi, I., Poole, S., Deeth, H. C., \& Dykes, G. A. (2009). Biogenic amines in fish: Roles in intoxication, spoilage, and nitrosamine formation-a review. Critical Reviews in Food Science and Nutrition, 49(4), 369-377.

AOAC. (1995). Official methods of analysis of AOAC international (16th ed.) (Horowitz, Washigton DC, USA).

ASTM. (2004). Annual book of ASTM standards. Philadelphia, PA, USA: ASTM International.

Bajpai, S. K., Chand, N., \& Ahuja, S. (2015). Investigation of curcumin release from chitosan/cellulose microcrystals (CMC) antimicrobial films. International Journal of Biological Macromolecules, 79, 440-448.

Biji, K. B., Ravishankar, C. N., Mohan, C. O., \& Srinivasa Gopal, T. K. (2015). Smart packaging systems for food applications: A review. Journal of Food Science and Technology, 52(10), 6125-6135.

Carvalho, R. A., Sobral, P. J. A., Thomazine, M., Habitante, A. M. Q. B., Giménez, B., Gómez-Guillén, M. C., et al. (2008). Development of edible films based on differently processed Atlantic halibut (Hippoglossus hippoglossus) skin gelatin. Food Hydrocolloids, 22, 1117-1123.

Condés, M. C., Añón, M. C., \& Mauri, A. N. (2015). Amaranth protein films prepared with high-pressure treated proteins. Journal of Food Engineering, 166, 38-44.

Denavi, G. A., Pérez-Mateos, M., Añón, M. C., Montero, P., Mauri, A. N., \& GómezGuillén, M. C. (2009). Structural and functional properties of soy protein isolate and cod gelatin blend films. Food Hydrocolloids, 23(8), 2094-2101.

Gontard, N., Duchez, C., Cuq, J. L., \& Guilbert, S. (1994). Edible composite films of wheat gluten and lipids: Water vapour permeability and other physical properties. International Journal of Food Science and Technology, 29, 39-50.

Govindaraj, P., Kandasubramanian, B., \& Kodam, K. M. (2014). Molecular interactions and antimicrobial activity of curcumin (Curcuma longa) loaded polyacrylonitrile films. Materials Chemistry and Physics, 147, 934-941.

Kerry, J. P. (2012). Application of smart packaging systems for conventionally packaged muscle-based food products. In J. P. Kerry (Ed.), Advances in meat, poultry and seafood packaging (pp. 522-564). Woodhead Publishing Limited.

Kuswandi, B., Jayus, A. R., Abdullah, A., Heng, L. Y., \& Ahmad, M. (2012). A nove colorimetric food package label for fish spoilage based on polyaniline film. Food Control, 25(1), 18-189.

Lawhavinit, O. A., Kongkathip, N., \& Kongkathip, B. (2010). Antimicrobial activity of curcuminoids from Curcuma longa $L$. on pathogenic bacteria of shrimp and chicken. Kasetsart Journal-Natural Science, 44(3), 364-371.

Liu, Y., Cai, Y., Jiang, X., Wu, J., \& Le, X. (2016). Molecular interactions, characterization and antimicrobial activity of curcumin-chitosan blend films. Food Hydrocolloids, 52, 564-572.

Maniglia, B. C. de Paula, R. L., Domingos, J. R., \& Tapia-Blácido, D. R. (2015). Turmeric dye extraction residue for use in bioactive film production: Optimization of turmeric film plasticized with glycerol. LWT - Food Science and Technology, 64, $1187-1195$.

Maniglia, B. C., Domingos, J. R., de Paula, R. L., \& Tapia-Blácido, D. R. (2014) Development of bioactive edible film from turmeric dye solvent extraction residue. LWT - Food Science and Technology, 56, 269-277.

Martins, N., Roriz, C. L. Morales, P., Barros, L, \& Ferreira, I. C. F. R. (2016). Food colorants: Challenges, opportunities and current desires of agroindustries to ensure consumer expectations and regulatory practices. Trends in Food Science \& Technology, 52, 1-15.

Mauri, A. N., \& Añón, M. C. (2006). Effect of solution pH on solubility and some structural properties of soybean protein isolate films. Journal of the Science of Food and Agriculture, 86(7), 1064-1072.

Mayet, N., Kumar, P., Choonara, Y. E., Tomar, L. K., Tyagi, C., du Toit, L. C., et al. (2014). Synthesis of a semi-interpenetrating polymer network as a bioactive curcumin film. AAPS PharmSciTech, 15(6), 1476-1489.

Mehanny, M., Hathout, R. M., Geneidi, A. S., \& Mansour, S. (2016). Exploring the use of nanocarrier systems to deliver the magical molecule; curcumin and its derivatives. Journal of Controlled Release, 225, 1-30.

Moghadamtousi, S. Z., Kadir, H. A., Hassandarvish, P., Tajik, H., Abubakar, S., \& Zandi, K. (2014). A review on antibacterial, antiviral, and antifungal activity of curcumin. BioMed Research International. http://dx.doi.org/10.1155/2014/ 186864.

Musso, Y. S., Salgado, P. R., \& Mauri, A. N. (2016). Gelatin based films capable of modifying its color against environmental pH changes. Food Hydrocolloids, 61, 523-530.

Niamsa, N., \& Sittiwet, C. (2009). Antimicrobial activity of Curcuma longa aqueous extract. Journal of Pharmacology and Toxicology, 4(4), 173-177.

Nur Hanani, Z. A., Roos, Y. H., \& Kerry, J. P. (2012). Use of beef, pork and fish gelatin sources in the manufacture of films and assessment of their composition and mechanical properties. Food Hydrocolloids, 29, 144-151.

Priyadarsini, K. I. (2014). The chemistry of curcumin: From extraction to therapeutic agent. Molecules, 19, 20091-20112.

Pulido-Moran, M., Moreno-Fernandez, J., Ramirez-Tortosa, C., \& RamirezTortosa, M. C. (2016). Curcumin and health. Molecules, 21, 264-286.

Ruiz-Capillas, C., \& Jiménez-Colmenero, F. (2005). Biogenic amines in meat and meat products. Critical Reviews in Food Science and Nutrition, 44(7-8), 489-599.

Salgado, P. R., Fernández, G. B., Drago, S. R., \& Mauri, A. N. (2011). Addition of bovine plasma hydrolysates improves the antioxidant properties of soybean and sunflower protein-based films. Food Hydrocolloids, 25(6), 1433-1440.

Salgado, P. R., López-Caballero, M. E., Gómez-Guillén, M. C., Mauri, A. N., \& Montero, M. P. (2012). Exploration of the antioxidant and antimicrobial capacity of two sunflower protein concentrate films with naturally present phenolic compounds. Food Hydrocolloids, 29(2), 374-381.

Salgado, P. R., López-Caballero, M. E., Gómez-Guillén, M. C., Mauri, A. N., \& Montero, M. P. (2013). Sunflower protein films incorporated with clove essential oil have potential application for the preservation of fish patties. Food Hydrocolloids, 33(1), 74-84.

Salgado, P. R., Molina Ortiz, S. E., Denavi, G. A., Bosch, M. A., Añón, M. C. \& Mauri, A. N. (2016). Influence of protein conformation on the properties of soybean protein edible films. In V. Kumar Thakur, M. Kumari Thakur, \& M. R. Kessler (Eds.), Soy-based bioplastics. UK Publisher.

Wang, Y. J., Pan, M. H., Cheng, A. L., Lin, L. I., Ho, Y. S., Hsieh, C. Y., et al. (1997) Stability of curcumin in buffer solutions and characterization of its degradation products. Journal of Pharmaceutical and Biomedical Analysis, 15(12), 1867-1876. 